\title{
Hemophagocytic Syndrome in a Patient with Adult-onset Still's Disease
}

\author{
Erişkin Başlangıçlı bir Still Hastasında Hemofagositik Sendrom \\ Yalkın ÇALIK, Safinaz ATAOĞLU, Ersun BAŞ, Selma YAZICI, Ali Erdem BAKİ, Metin YAVUZ \\ Departments of Physical Medicine and Rehabilitation, Medical Faculty of Düzce University, Düzce, Turkey
}

\begin{abstract}
Hemophagocytic syndrome is a fatal and life-threatening syndrome characterized by pancytopenia and multiple organ failure. It can frequently be seen in childhood as a primary or familial condition. In adults, it occurs secondarily. In etiology, wide range of factors are related to this syndrome. Adult-onset Still's disease seems to be one of the systemic rheumatological diseases that cause this syndrome. In our literature review, we found few studies related to this syndrome. In this article, we report a 40-year-old female patient who had been treated with the diagnosis of Adultonset Still's disease for four years in our clinic and who developed hemophagocytic syndrome during her follow-ups.

Key words: Adult-onset still's disease; hemophagocytic syndrome; hemophagocytosis.
\end{abstract}

Adult-onset Still's disease (AOSD) is a systemic inflammatory disease which has unknown etiology and pathology. ${ }^{[1]}$ It is characterized by quotidian or double quotidian spiking fevers $\left(>39^{\circ} \mathrm{C}\right)$, sore throat, diffuse myalgias, arthralgias and evanescent rash. ${ }^{[2]}$ The disease affects younger people more than adults with peaks at 15-25 and 36-46 years of age. ${ }^{[3]}$ Erythrocyte sedimentation rate (ESR) and C-reactive protein (CRP) are elevated. Rheumatoid factor (RF) and antinuclear antibody (ANA) are negative. Common haematological abnormalities include leukocytosis and thrombocytosis. ${ }^{[4]}$ Non-steroid antiinflammatory drugs (NSAID's), corticosteroids and disease modifying anti- rheumatic drugs (DMARD's), especially methotrexate (MTX), are used in the treatment of AOSD. ${ }^{[5]}$ Hemophagocytic syndrome
Hemofagositik sendrom pansitopeni ve çoklu organ yetmezliği ile karakterize ölümcül ve yaşamı tehdit edici nitelikte bir sendromdur. Çocukluk çağında sıklıkla primer veya ailesel olarak görülebilir. Yetişkinlerde sekonder olarak görülür. Etyolojide birçok farklı etken bu sendrom ile ilişkilidir. Erişkin başlangıçlı Still hastalığı bu sendroma neden olan sistemik romatolojik hastalıklardan biriymiş gibi görünmektedir. Literatür taramasında bu sendromla ilgili az sayıda çalışmaya rastladık. Bu yazıda, kliniğimizde dört yıldır erişkin başlangıçı Still hastalığı tanısı ile tedavi edilen ve takiplerinde hemofagositik sendrom gelişen 40 yaşında bir kadın hasta sunuldu.

Anahtar sözcükler: Erişkin başlangıçlı Still hastalığı; hemofagositoz; hemofagositik sendrom.

(HS) is a rare potentially fatal disease that shares several clinical and laboratory features including pancytopenia hepatosplenomegaly, elevated liver enzymes, hyperferritinemia and hypertriglyceridemia. Various etiological factors are related to this syndrome. Adult-onset Still's disease seems to be the main underlying systemic disease. ${ }^{[6]}$ In light of the literature, we aimed to show the clinical features of HS in an AOSD patient.

\section{CASE REPORT}

A 40-year-old female patient who has been treated as AOSD for four years was referred to our clinic with complaining of high spiking fever, myalgias, sore throat and weakness. Concomitantly she was observed to have a maculopapular skin rash on her 
forearms which had appeared 10 days previously. She was hospitalized with her complaints. In her medical history, she was treated as AOSD with MTX $10 \mathrm{mg} /$ week. On the second visit, the MTX dose was increased to $15 \mathrm{mg} /$ week. Her vomiting improved, so she stopped using MTX. After she was hospitalized, a physical examination revealed diffuse myalgias, arthralgias of hip and knees, a symmetrical pink maculopapular style of evanescent rash and a high spiking fever. The fever was normal from 6:00 AM to 3:00 PM as $36.0{ }^{\circ} \mathrm{C}$, but it increased from 3:00 PM to 6:00 AM. The highest temperature was seen at 2:00 AM as $39.6{ }^{\circ} \mathrm{C}$. Laboratory data was as follows: leucocytes (WBC): $23450 / \mathrm{mm}^{3} \quad(\mathrm{n}=5200-12400)$, neutrophils (NEU): $22060 / \mathrm{mm}^{3}$ ( $\left.\mathrm{n}=1900-8000\right)$, hemoglobin (Hb): $12.0 \mathrm{~g} / \mathrm{dl}(\mathrm{n}=12-18)$, hematocrit $(\mathrm{Htc}): 37.4 \%(\mathrm{n}=37-52)$, mean corpuscular volume (MCV): $82.7 \mathrm{fL}(\mathrm{n}=80-99)$, erythrocytes (RBC): $4.21 \times 106 / \mathrm{mm}^{3}$ (n:4.20-6.10x106), platelets (Plt): $478000 / \mathrm{mm}^{3}(\mathrm{n}=130000-400000), \mathrm{ESR}$ : $92 \mathrm{~mm} / \mathrm{h}(\mathrm{n}=0-25)$, CRP: $30.0 \mathrm{mg} / \mathrm{dl}(\mathrm{n}=0-0.5)$, alanine aminotransferase (ALT): 22 IU/l $(\mathrm{n}=0-55)$, aspartate aminotransferase (AST): 19 IU/l $(\mathrm{n}=0-27)$, total cholesterol (TC): $107 \mathrm{mg} / \mathrm{dl}(\mathrm{n}=120-200)$, triglyceride (TG):117 mg/dl ( $\mathrm{n}=40-150)$, vitamin-B12: $961 \mathrm{pg} / \mathrm{ml}$ $(\mathrm{n}=197-866)$, ferritin: $11052 \mathrm{ng} / \mathrm{ml}(\mathrm{n}=15-150)$, lactic dehydrogenase (LDH): 1338 IU/l $(n=0-480)$, RF: $11.2 \mathrm{IU} / \mathrm{l}(\mathrm{n}=0-14)$. The antinuclear antibody was negative, and blood, urine and throat cultures remained sterile. Serologies for Epstein-Barr virus (EBV), Cytomegalovirus (CMV), Hepatitis B virus (HBV), Hepatitis C virus (HCV), Varicella-zoster virus (VZV) were negative. She was given oral tenoxicam $10 \mathrm{mg} /$ day, oral methylprednisolone $60 \mathrm{mg} /$ day and oral amoxicillin $1 \mathrm{mg} / \mathrm{kg} /$ day at the treatment. On the $4^{\text {th }}$ day of hospitalization, her clinical condition was worse with abdominopelvic pain and her vital signs were blood pressure: 90/60 $\mathrm{mmHg}$, fever: $39.7{ }^{\circ} \mathrm{C}$, pulse: $95 / \mathrm{dk}$. Laboratory data was as follows: WBC: $1026 / \mathrm{mm}^{3}$, NEU: $274 / \mathrm{mm}^{3}$, Hb: $6.2 \mathrm{mg} / \mathrm{dl}$, Htc: 17.9\%, RBC: $1.41 \times 106 / \mathrm{mm} 3$, PLT: $8000 / \mathrm{mm} 3$, ESR: $131 \mathrm{~mm} / \mathrm{h}$, CRP: $29.58 \mathrm{mg} / \mathrm{dl}$, ALT: $169 \mathrm{IU} / \mathrm{l}$, AST: $106 \mathrm{IU} / \mathrm{l}$, TC: $224 \mathrm{mg} / \mathrm{dl}$, TG: $208 \mathrm{mg} / \mathrm{dl}$, vitamin-B12: $1018 \mathrm{pg} / \mathrm{ml}$, ferritin: $11124 \mathrm{ng} / \mathrm{ml}, \mathrm{LDH}: 1320 \mathrm{IU} / \mathrm{l}$. For febrile neutropenia and pancytopenia, a bone marrow puncture-biopsy was examined. It revealed increased proliferation of benign macrophages with hemophagocytosis (Figure 1). Abdominopelvic ultrasonography revealed that vertical length of spleen was $15 \mathrm{~cm}$. Then the patient was diagnosed with hemophagocytic syndrome. On that day the patient was given two units of blood and two units of erythrocyte suspensions. Methylprednisolone $80 \mathrm{mg} /$ day intravenous and granulocyte colonystimulating factor (G-CSF) were added to the treatment for four consecutive days. On the first week of the follow-up, the patient's clinical condition was better. Granulocyte colony-stimulating factor was discontinued, and methylprednisolone was continued to be given at $80 \mathrm{mg}$ iv/day. On the second week omitted, laboratory data was normalized as follows: WBC: $8690 / \mathrm{mm}^{3}$, NEU: $6130 / \mathrm{mm}^{3}, \mathrm{Hb}: 12.7 \mathrm{gr} / \mathrm{dl}$, Htc: $38.3 \%$, MCV: 84 fL, RBC: 4.63x106, Plt: 358000 $/ \mathrm{mm}^{3}$, ESR: $21 \mathrm{~mm} / \mathrm{h}, \mathrm{CRP}: 0.5 \mathrm{mg} / \mathrm{dl}$, ALT: $18 \mathrm{IU} / \mathrm{l}$, AST: 23 IU/l, TC: $161 \mathrm{mg} / \mathrm{dl}$, TG: $105 \mathrm{mg} / \mathrm{dl}$, ferritin: $147 \mathrm{ng} / \mathrm{ml}, \mathrm{LDH}: 247 \mathrm{IU} / \mathrm{l}$. Then the steroid dose was tapered. Her treatment was regulated before being discharged.

\section{DISCUSSION}

Hemophagocytic syndrome is a rare and fatal syndrome that is characterized by multiple organs failure and hemophagocytosis. ${ }^{[7]}$ Risdall et al. ${ }^{[8]}$ first described a group of patients with HS. It's a clinicopathological entity that has clinical diagnostic criteria such as fever $\left(>39{ }^{\circ} \mathrm{C}\right)$, hepatosplenomegaly pancytopenia, raised levels of liver enzymes, serum ferritin, triglycerides and hemophagocytosis. ${ }^{[6]}$ It may be caused by activation and uncontrolled non-malignant proliferation of $\mathrm{T}$ lymphocytes and macrophages with hemophagocytosis throughout the reticuloendothelial system. ${ }^{[9]}$ Recent studies show it can be idiopathic essentially in childhood, or it can be secondary related to various situations such as infections, malignancies, drugs and systemic rheumatological diseases in adults. ${ }^{[10]}$ Adult-onset Still's disease seems to be one of the

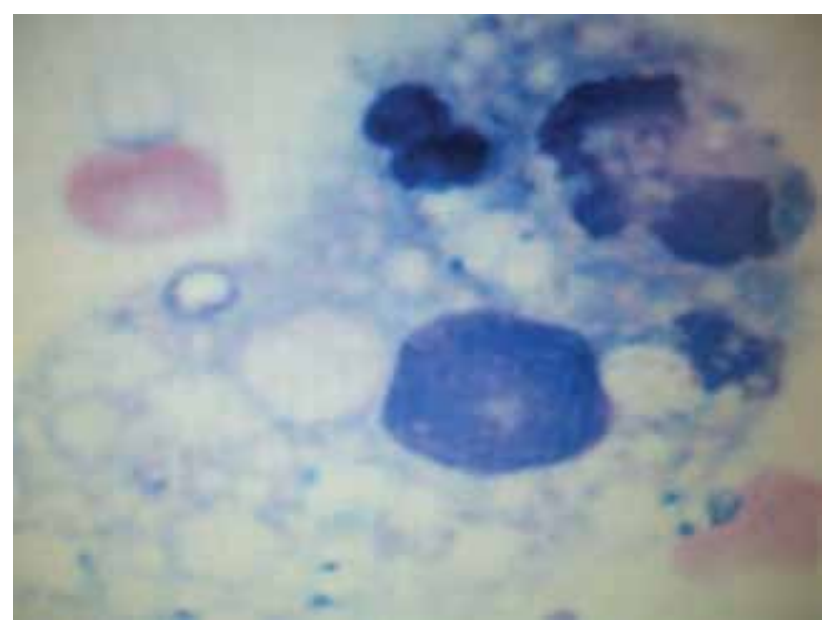

Figure 1. Hemophagocytosis in a bone marrow aspirate. 
systemic rheumatological diseases according to the definition of HS. Hemophagocytic syndrome shares similar clinical and laboratory features with AOSD. ${ }^{[6]}$ Hadchouel et al. ${ }^{[1]}$ showed that the relationship is related to rheumatic diseases with HS. Emmenegger et al. ${ }^{[10]}$ pointed out that 40 percent of patients with HS shared similar clinical features with AOSD. Adult-onset Still's disease is a systemic, inflammatory disease that has unknown etiology. Bywaters $^{[1]}$ presented in 14 adult patients the first description of AOSD. Adult-onset Still's disease typically manifests clinical features including high spiking fever $\left(>39^{\circ} \mathrm{C}\right)$, evanescent, a salmon-pink rash with maculopapular pattern, arthritis, arthralgias, sore throat and myalgias. Laboratory findings such as elevated CRP and ESR, hyperferritinemia, anemia, thrombocytosis, leukocytosis are seen. Antinuclear antibody and RF are negative. ${ }^{[4,5]}$ The main differences between the two diseases are cutaneous, articular involvement and different hematological findings. ${ }^{[12]}$ Thrombocytosis and leukocytosis are present in AOSD but pancytopenia is present in HS. The development of cytopenias is an important feature of this syndrome. Ferritin is an acute phase reactant, and hyperferritinemia shows acute disease activation of AOSD. The clinical presentation of AOSD is heterogeneous, and the differential diagnosis is wide including infectious, neoplastic and autoimmune diseases which should be ruled out before the diagnosis of AOSD can be made. ${ }^{[13]}$ Non-steroidal antiinflammatory drugs and steroid DMARD's, are used for the treatment of AOSD. ${ }^{[14]}$ In our case, we made a differential diagnosis between neoplastic diseases especially leukemias, lymphomas, drugs (especially MTX), and infectious diseases that originated from viruses. There were no blastic cells of leukemias and lymphomas in the bone marrow puncture-biopsy or any isolated lymph node enlargement in our patients. The serological cultures were sterile so we did not think any viral infectious and neoplastic diseases were triggers of HS in our patient. Methotrexate was used as a DMARD for AOSD in the treatment. Nakazaki et al. ${ }^{[15]}$ reported that hematological toxicity of MTX was more frequent in patients with high levels of MCV. Weinblatt and Fraser ${ }^{[16]}$ reported that MTX was a risk factor for high MCV levels. Pancytopenia, a rare complication of MTX toxicity, is demonstrated with a percentage of 3 in MTX treatment. ${ }^{[17]}$ In our patient, MCV had normal values. Guler et al. ${ }^{[18]}$ reported that the hypercellularity observed in the bone marrow aspirates indicated that the event was MTX-related.
In our patient, hemophagocytosis was indicated in the bone marrow aspirate, so we didn't consider MTX toxicity. Therefore, MTX-induced hemophagocytosis was eliminated in our patient. We finally showed in our patient AOSD triggered HS.

In conclusion, we think that clinicians must be careful and tolerant in clinic observations with the AOSD patients.

\section{Declaration of conflicting interests}

The authors declared no conflicts of interest with respect to the authorship and/or publication of this article.

\section{Funding}

The authors received no financial support for the research and/or authorship of this article.

\section{REFERENCES}

1. Bywaters EG. Still's disease in the adult. Ann Rheum Dis 1971;30:121-33.

2. Larson EB. Adult Still's disease-recognition of a clinical syndrome and recent experience. West J Med 1985;142:665-71.

3. Magadur-Joly G, Billaud E, Barrier JH, Pennec YL, Masson C, Renou P, et al. Epidemiology of adult Still's disease: estimate of the incidence by a retrospective study in west France. Ann Rheum Dis 1995;54:587-90.

4. Pouchot J, Sampalis JS, Beaudet F, Carette S, Décary F, Salusinsky-Sternbach M, et al. Adult Still's disease: manifestations, disease course, and outcome in 62 patients. Medicine (Baltimore) 1991;70:118-36.

5. Larson EB. Adult Still's disease. Evolution of a clinical syndrome and diagnosis, treatment, and follow-up of 17 patients. Medicine (Baltimore) 1984;63:82-91.

6. Karras A, Hermine O. Hemophagocytic syndrome. Rev Med Interne 2002;23:768-78. [Abstract]

7. Aricò M, Danesino C, Pende D, Moretta L. Pathogenesis of haemophagocytic lymphohistiocytosis. Br J Haematol 2001;114:761-9.

8. Risdall RJ, McKenna RW, Nesbit ME, Krivit W, Balfour HH Jr, Simmons RL, et al. Virus-associated hemophagocytic syndrome: a benign histiocytic proliferation distinct from malignant histiocytosis. Cancer 1979;44:993-1002.

9. Ravelli A. Macrophage activation syndrome. Curr Opin Rheumatol 2002;14:548-52.

10. Emmenegger U, Reimers A, Frey U, Fux Ch, Bihl F, Semela D, et al. Reactive macrophage activation syndrome: a simple screening strategy and its potential in early treatment initiation. Swiss Med Wkly 2002;132:230-6.

11. Hadchouel M, Prieur AM, Griscelli C. Acute hemorrhagic, hepatic, and neurologic manifestations in juvenile rheumatoid arthritis: possible relationship to drugs or infection. J Pediatr 1985;106:561-6. 
12. Reiner AP, Spivak JL. Hematophagic histiocytosis. A report of 23 new patients and a review of the literature. Medicine (Baltimore) 1988;67:369-88.

13. Efthimiou P, Paik PK, Bielory L. Diagnosis and management of adult onset Still's disease. Ann Rheum Dis 2006;65:564-72.

14. Aydintug AO, D'Cruz D, Cervera R, Khamashta MA, Hughes GR. Low dose methotrexate treatment in adult Still's disease. J Rheumatol 1992;19:431-5.

15. Nakazaki S, Murayama T, Katoh S. Cytopenia associated with low dose pulse methotrexate in the treatment of rheumatoid arthritis. Ryumachi 2001;41:929-37. [Abstract]

16. Weinblatt ME, Fraser P. Elevated mean corpuscular volume as a predictor of hematologic toxicity due to methotrexate therapy. Arthritis Rheum 1989;32:1592-6.

17. Preet Singh Y, Aggarwal A, Misra R, Agarwal V. Low-dose methotrexate-induced pancytopenia. Clin Rheumatol 2007;26:84-7.

18. Güler N, Tander B, Kısacık B, Utku U, Çevik A, Erçolak V, et al. Low dose methotrexate associated pancytopenia with rheumatoid arthritis. Turk J Phys Med Rehab 2008;54:79-81. 